\title{
Modelling Macroeconomic and Bank-Specific Determinants of Credit Risk in the Nigerian Banking Sector: Evidence from Bounds Test Approach to Co-Integration
}

\author{
Stanley C. Duruibe, MSc \\ Nathaniel C. Nwezeaku, PhD \\ Aghalugbulam B.C. Akujuobi, PhD \\ Sampson Ikenna Ogoke, $M S c$ \\ Chidinma Elizabeth Nwabeke, MSc \\ Department of Financial Management Technology, \\ Federal University of Technology, Owerri, Imo State, Nigeria
}

Doi:10.19044/esj.2021.v17n32p221

Submitted: 27 May 2021

Accepted: 21 September 2021

Published: 30 September 2021
Copyright 2021 Author(s)

Under Creative Commons BY-NC-ND

4.0 OPEN ACCESS

Cite As:

Duruibe S.C., Nwezeaku N.C., Akujuobi A.B.C., Ogoke S.I. \& Nwabeke C.E. (2021). Modelling Macroeconomic and Bank-Specific Determinants of Credit Risk in the Nigerian Banking Sector: Evidence from Bounds Test Approach to Co-Integration. European Scientific Journal, ESJ, 17 (32), 221. https://doi.org/10.19044/esj.2021.v17n32p221

\begin{abstract}
Credit risk, represented in this study by the ratio of non-performing loans to total loan (NPL), is considered as one of the critical factors that causes bank distress and failure. This study examines the macroeconomic and bankspecific determinants of credit risk in the Nigerian Banking sector from the period 1998Q1 to 2018Q4 using the bounds test approach to co-integration. Literature survey in this subject area using Google Scholar resources reveals that there seems to be a consensus of findings in terms of the negative relationship between credit risk and Gross Domestic Product (GDP) growth rate, while other macroeconomic and bank-specific factors tend to have a random pattern relationship with credit risk attributable to various countries' economic peculiarities. This study shows that GDP growth rate, return on asset, return on equity, interest rate, unemployment rate, and real exchange rate have a negative relationship with NPL. On the other hand, inflation rate, loan deposit ratio, and ratio of bank capital to asset have positive relationship with NPL. The relationships between the three variables and NPL were found to be individually insignificant to explain credit risk trends in the long run.
\end{abstract}


Moreover, the Wald short-run causality test reveals that the macroeconomic and bank specific indicators jointly influence credit risk in the Nigeria banking sector in the short run. This study, however, recommends that since the macroeconomic and bank specific factors were found to be individually insignificant to explain credit risk trend in the long run, consideration should be accorded to some psychological, political, and socioeconomic factors such as the borrower's attitude, business climate, social dislocations and distortions, availability of good infrastructural facilities, and the direction of government policies. These factors can affect borrowers' ability to honor their debt obligations and, thus, determine the level of credit risk in the Nigerian economy.

Keywords: Credit Risk, Bounds test, Wald test, Nigerian Banking sector

\section{Introduction}

The primary role of the banking system in any economy is to provide a linkage between those with excess funds (or surplus unit) and those with shortage of funds (or deficit unit). Excess fund holders normally initiate cash deposits with deposit money banks in order to safeguard their funds, sometimes in return for interest payment by the banks. The banks use these deposited funds to grant credits to those who wish to engage in one form of economic activity or the other but are faced with shortage of funds. The deficit unit receives these credits in lieu of regular interest payments to the banks and, thereafter, principal repayment at the maturity of the loan tenure. This is because these loans constitute one of the greatest assets of the banks, and banks are obliged to make depositors' funds available to them whenever they need it to necessitate proper credit management by banks in order to forestall credit risk. Credit risk is the risk of default on a loan that may arise from a borrower failing to make required payments, and this risk may cause the lender to loss the principal and/or interest. Specifically, it refers to the risk that the lender may not recover the owed principal and interest on the loan, which leads to an interruption of cash-flows and increased cost for collection to the lender ("Credit Risk", n.d). "Banks' exposure to credit risk is one of the major causes of banking distress" (Chaibi \& Ftiti, 2015, p 2). Distress in the banking industry has its attendant negative impact on economic growth and development of any nation.

In recent times, due to the negative impact of banking distress on several national economies-reinforced by the financial crisis of 2008/2009, there have been concerted efforts by scholars to find out factors that cause bank credit risk. In addition, findings from their enquiries so far has provided conflicting opinions on the approach, and causes of credit risk in the banking industry (Ali \& Daly, 2010; Ahmad, 2003; Ariff \& Marisetty, 2001; Nkusu, 
2011; Bofondi \& Ropele, 2011; Louzis et al., 2012; etc.). Alas, several of these studies concentrate on developed economies most likely due to data availability, while there are just a few studies in this area that focus on developing economies such as Nigeria. Moreover, the main body of the literature on credit risk determinants is dominated by panel data/cross-country studies which do not encompass country-specific features. The available single country analysis is constrained by the variety of credit risk determinants evaluated or the short time intervals investigated. Thus, this study fills this lacuna by focusing on the macroeconomic and bank-specific determinants of credit risk in the Nigerian banking sector. Credit risk in this study is measured as the ratio of non-performing loans (NPLs) to total gross loans in the banking sector in Nigeria, and the time frame chosen is between 1998Q1- 2018 Q4. This time frame is very strategic because it coincides with the era of the global financial crises and the post crisis era.

Succinctly, the main purpose of this study is to have an insight on the factors that determine credit risk in the Nigerian banking sector. Therefore, this study will be of immense benefit to policy makers in government, economic and finance scholars, and monetary authorities.

\section{Literature Review}

The sections that follow review the background of the Nigerian banking sector and the empirical and theoretical literature in this subject area.

\subsection{Contextual Framework of the Nigerian Banking Sector}

The banking sector of Nigeria is the second-largest in Africa following South Africa. Reports by Research and Markets (2020) pinpoint that in May 2020, total assets stood at N42 trillion (naira). Some of the smaller Nigerian banks are fighting to boost their capital levels after a crash in oil prices brought about by an economic downturn in 2016 and foreign currency crisis, which made it difficult for firms to repay loans owed to the banks. Hence, this increases the amount of non-performing loans in the banking sector.

Some scholars argue that the larger banks in the sector were guilty of careless lending to the oil sector when the price of crude oil was very high; and when the price of crude oil fell, the larger banks became vulnerable to credit crises. Nonetheless, sometime in 2017, the price of crude oil rose again and these banks began another round of lending to the oil sector.

Issues of great concern to the banking sector are sluggish economic growth and vulnerability to uncertainty in crude oil prices.

The issue of corporate governance is one of the greatest problems bedeviling the Nigerian banks, as well as the financial irresponsibility and misconduct by executive management which have hampered their performance and sustainability. No foreign bank has entered the Nigerian 
banking sector in the last ten years. The Central Bank of Nigeria regulations stipulate that the total amount of investment by foreign banks in any of the 10 biggest indigenous banks should not exceed $10 \%$ of their total capital.

\subsection{Empirical and Theoretical Literature Review}

The global financial crisis of 2008/2009 has spark-off a renewed interest among academics on the determinants of credit risk in the banking sector. This is necessary because understanding the determinants of credit risk will help policy makers to take the needed steps to avert possible financial distress (Castro, 2013).

Accordingly, existing literature on the determinants of credit risk have emerged with two sets of factors that determine credit risk: they are the macroeconomic and bank specific factors. The macroeconomic factors relate to the economic-wide conditions that positively or negatively affect the ability of borrowers to service their debt. For instance, a stable economic growth boosts real income and minimizes the likelihood that a potential borrower will not be able to service his debt as he will have more disposable income. Furthermore, as the GDP and other monetary aggregates grow, the NPLs in the banking sector are minimized. On the flip side, high unemployment rate will increase the likelihood that potential borrowers will not be able to service their debt as they will have less disposable income. Thus, as unemployment rises, NPLs also rises. Succinctly, NPLs are negatively and positively affected by GDP growth and rise in unemployment respectively (Messai \& Jouini, 2013). Other economic-wide factors considered in the theoretical literature on determinants of credit risk are: the real interest rate, the inflation rate, and the real exchange rate. The relationship between interest rate and NPLs is positive since a high interest rate increases debt burden and ultimately NPLs (Nkusu, 2011). As far as the exchange rate is concerned, its effect on credit risk is vague. The effect of exchange rates on NPLs can be positive or negative depending on the debt currency. To shed more light on this, loans in foreign currency are aided by the local currency appreciations which make them cheaper for borrowers, thereby reducing the tendency of NPLs; the reverse is the case when local currency depreciates (Mishkin, 1996; Nkusu, 2011). The same ambiguous fate applies to inflation rate as it could be positive or negative. Higher inflation rates diminish the real value of existing loans, thereby lessening the debt service obligation (Castro, 2013). On the flip side, in places where variable interest rates are in place, due to higher inflation, lenders adjust interest rates to reflect their real values. Hence, debt servicing becomes more difficult for inflation-induced-reduced-income earners who have to pay higher interest rates.

Empirical evidences from the literature on credit risk determinants also reveal that bank specific factors such as asset quality, credit growth, bank 
capital, bank liquidity, and bank profitability among others, influence credit risk of financial institutions (Angbazo, 1997; Cheng, 2008; Castro, 2013; Gavin \& Haussmann, 1996; Berger \& DeYoung, 1997; Vogiazas \& Nikolaidou, 2011; Louzis et al., 2012). Specifically, Angbazo (1997) and Cheng (2008) studies reveal that banks earning assets to total assets which reflect management efficiency has a negative correlation with banks credit risk, implying that efficient credit risk management includes proper credit risk environment, good credit granting process, and sustaining suitable credit administration (Greuning \& Bratanovic, 2003; Derban et al., 2005). Moreover, rapid credit growth is often associated with a parallel increase of impaired loans (Castro, 2013). The moral hazard hypothesis points out that banks with low capital have the tendency of undertaking excessive lending, thereby exposing them to risks such as greater loan losses (Gavin \& Haussmann, 1996; Berger \& DeYoung, 1997). Furthermore, according to the moral hazard theory, banks with low liquidity will also report higher NPLs (Vogiazas \& Nikolaidou, 2011). The impact of bank profitability captured by profitability ratios such as ROA and ROE is ambiguous, and it is well stated by Louzis et al. (2012) through the bad management and pro-cyclical credit policy theory. According to this theory, banks' performance has a negative relationship with future NPLs due to low profitability as a result of poor management, which implies poor skills in credit evaluation and monitoring which translate to more chances of default. Although the pro-cyclical credit policy hypothesis also claims that good performance has a positive association with future increases in NPLs since bank managers are often interested not only in maximizing profit, it also helps in improving their reputation. For instance, bank managers may indulge in a liberal credit policy at the expense of future NPLs in an attempt to boost the bank's profitability in the eyes of the market. Thus, current earnings may help pile up NPLs in the future.

Going further, empirical evidence from country/cross-country level determinants of credit risk abound in the literature. Most of these countries' level analysis emerges with divergent results due to distinctiveness in the methodology and variables employed. Moreover, most of these studies focus on cross-country analysis. Makri et al. (2014) studied 14 Euro zone countries over the pre-crisis period between 2000-2008 and found that NPLs are strongly correlated with several macroeconomic factors such as public debt, unemployment, GDP growth; and bank-specific factors such as return on equity and capital adequacy ratio. The preceding results were also achieved by Louzis et al. (2012) when a group of Greek banks was analyzed by Mesai and Jouini (2013) for Spain, Italy, and Greece. Demirguc-Kunt and Detragiache (1997) claim that the banking distress that some developed and developing economies witnessed between the period 1980 and 1994 was a result of weak macroeconomic environment depicted by high inflation rate, sluggish GDP 
growth rate along with banks' low liquidity, and a high share of bank credit to the private sector. Correspondingly, Pesola (2005) studied a group of industrial countries and found that sudden shocks on real interest rates and income aid the distress in the banking industry. Kakvler and Festic (2012) in their study of Bulgaria and Romania between 1997 and 2008 argued that enormous current account deficits due to structural dependence on external financing may lead to financial instability, thus, increasing NPLs. Bofondi and Ropele (2011) found that NPLs in Italy are determined by macroeconomic factors such as economic growth, the cost of borrowing, and the debt burden from the period 1990-2010. Similarly, using cross-country data for both emerging and advanced countries, Liang and Reichert (2012) found that ineffective credit regulations, low capital adequacy ratios, poor institutional capacity, mandatory guidelines on pattern of credit allocation by the government, and regulatory authorities and absence of regulation by the regulatory bodies worsen credit risk in the banking sector. Salas and Saurina (2002) studied credit risk determinants in Spanish commercial and savings banks between the period of 1985 and 1997 and found that GDP growth rate, firm and family indebtedness, previous credit expansion, portfolio composition, net interest margin, capital ratio, and market power contributed to credit risk. Using the VAR technique, Klein (2013) found that bank credit risk in Central, Eastern, and South-Eastern Europe (CESEE) is affected by both macroeconomic and bank-specific factors such as GDP growth rate, unemployment rate, inflation rate, profitability, level of equity, and excessive risk taking of the banks. In addition to that, a bi-directional relationship between credit risk and macroeconomic downturns was observed, which implies that countries that face loan crises are vulnerable to economic downturn.

Furthermore, there seems to be a consensus of findings in the literature in terms of the negative relationship between credit risks and GDP growth rate. All other macroeconomic and bank-specific factors tend to have an unspecified relationship with credit risk, and their nature of interaction follows a random pattern due to countries' peculiarities. Thus, this study aims to evaluate the determinants of credit risk in the Nigerian Banking sector, as a country which has the second largest banking sector (in terms of assets) in the Sub-Saharan African region.

\section{Research Data and Methodology}

The data for this study was sourced from the World Bank Databank and the Central Bank of Nigeria statistical Bulletin of 2018. The study timeframe spans from 1998Q1-2018Q4. Given that the Nigerian banking sector was badly hit by the global financial crisis of 2008/2009, this time frame 
is considered very strategic because it covers equal periods before and after the global financial crises.

Based on the time frame adopted, the included number of observations per variable is 84 ; hence, it is amenable to the Augmented Dickey Fuller (1979) ADF unit root test, Dickey-Fuller GLS (ERS) DF-GLS unit root test, and the Phillips and Perron (1988) PP unit root test techniques. This is because the probabilities and critical values of these three tests are calculated for at least 20 observations. However, according to Katircioglu, Feridun and Kilinc (2014), Jafari, Othman and Nor (2012), Behera and Dash (2017) and Farhani and Ozturk (2015), the PP and ADF unit root tests have a lower power of rejecting the null hypothesis. Thus, the Kwiatkowski, Phillips, Schmidt, and Shin (1992) KPSS unit root test surpasses the ADF and PP unit root test in eliminating a possible low power against stationary unit root that occurs in them. KPSS has the additional advantage of yielding consistent results for variables with lower number of observations. Based on the foregoing, the KPSS unit root test was adopted. Having found the variables stationary at levels $[\mathrm{I}(0)]$ and first difference [I(1)], the bounds co-integration test was conducted in order to establish the existence of co-integration among the variables or not. Having established co-integration, the long run error correction model given below was estimated:

$\Delta N P L_{t}=\alpha_{0}+\sum_{x}^{p}=i \alpha_{1 i} \Delta N P L_{t-i}+\sum_{x}^{q}=i \alpha_{2 i} \Delta G D P_{t-1}+\sum_{x}^{q}=i \alpha_{3 i} \Delta I N F_{t-1}+$ $\sum_{x} x^{q}=i \alpha_{4 i} \Delta I N T_{t-1}+\sum_{x} x^{q}=i \alpha_{5 i} \Delta U N E M P_{t-1}+\sum_{x}^{q}=i \alpha_{6 i} \Delta E X C H_{t-1}+\sum_{x}{ }^{q}=i \alpha_{7 i} \Delta L D R_{t-1}+$ $\sum^{q}{ }^{q}=i \alpha_{8 i} \Delta R O A_{t-1}+\sum_{x}^{q}=i \alpha_{9 i} \Delta R O E_{t-1}+\sum_{x}^{q}=i \alpha_{10 i} \Delta B C A R_{t-1}+\lambda E C T_{t-1}+e_{t}$

WHERE:

NPL $=$ Ratio of Non-Performing Loans to Total Loans.

GDP= Gross Domestic Product Annual Growth Rate- A Proxy for Economic Growth.

$\mathrm{INF}=$ Inflation Rate.

INT= Interest Rate.

UNEMP= Unemployment Rate.

$\mathrm{EXCH}=$ Real Exchange Rate.

LDR= Loan Deposit Ratio.

ROA $=$ Return on Asset- A Proxy for Bank Profitability.

ROE $=$ Return on Equity- A Proxy for Bank Profitability.

$\mathrm{BCAR}=$ Bank Capital to Asset Ratio.

$\lambda=\left(1-\sum^{\mathrm{p}_{\mathrm{i}=1}} \mathrm{gi}\right)=$ Speed of adjustment parameter with negative sign.

$\mathrm{ECT}=\left(\mathrm{NPL}_{\mathrm{t}-\mathrm{I}}-\Theta N \mathrm{NL}_{\mathrm{t}}\right)=$ Error Correction Term.

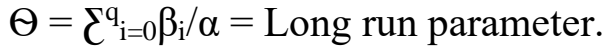

$\alpha_{1 \mathrm{i}} \alpha_{2 \mathrm{i}}, \ldots \ldots \ldots \alpha_{10 \mathrm{i}}=$ the short run dynamic coefficients of the model's adjustment to long run equilibrium. 
While GDP, INF, INT, UNEMP, and EXCH are macroeconomic variables captured in the model; LDR, ROA, ROE, and BCAR are the bank specific factors.

\section{Data Analysis, Empirical Results and Discussion}

Table 1. Kwiatkowski-Phillips-Schmidt-Shin (KPSS) Unit Root Output $\mathrm{H}_{0}=$ Variable is stationary; $\mathrm{H}_{1}=$ Variable is not stationary

\begin{tabular}{|c|c|c|c|}
\hline Variables & Order of Integration & KPSS Test Statistics & Critical Values at 5\% \\
\hline \multirow[t]{2}{*}{ NPL } & $\mathrm{I}(0)$ & 0.569236 & $0.463000 *$ \\
\hline & $\mathrm{I}(1)$ & 0.041963 & $0.463000 * *$ \\
\hline \multirow[t]{2}{*}{ GDP } & $\mathrm{I}(0)$ & 0.363529 & $0.463000 * *$ \\
\hline & $\mathrm{I}(1)$ & - & - \\
\hline \multirow[t]{2}{*}{ INF } & $\mathrm{I}(0)$ & 0.068318 & $0.463000 * *$ \\
\hline & $\mathrm{I}(1)$ & - & - \\
\hline \multirow[t]{2}{*}{ INT } & $\mathrm{I}(0)$ & 0.220203 & $0.463000 * *$ \\
\hline & $\mathrm{I}(1)$ & - & - \\
\hline \multirow[t]{2}{*}{ UNEMP } & $\mathrm{I}(0)$ & 0.542821 & $0.463000 *$ \\
\hline & $\mathrm{I}(1)$ & 0.334843 & $0.463000 * *$ \\
\hline \multirow[t]{2}{*}{ EXCH } & $\mathrm{I}(0)$ & 0.135861 & $0.463000 * *$ \\
\hline & $\mathrm{I}(1)$ & - & - \\
\hline \multirow[t]{2}{*}{ LDR } & $\mathrm{I}(0)$ & 0.077054 & $0.463000 * *$ \\
\hline & $\mathrm{I}(1)$ & - & - \\
\hline \multirow[t]{2}{*}{ ROA } & $\mathrm{I}(0)$ & 0.107049 & $0.463000 * *$ \\
\hline & $\mathrm{I}(1)$ & - & - \\
\hline \multirow[t]{2}{*}{ ROE } & $\mathrm{I}(0)$ & 0.338915 & $0.463000 * *$ \\
\hline & $\mathrm{I}(1)$ & - & - \\
\hline \multirow[t]{2}{*}{ BCAR } & $\mathrm{I}(0)$ & 0.137658 & $0.463000 * *$ \\
\hline & $\mathrm{I}(1)$ & & \\
\hline
\end{tabular}

Source: Eviews10. *Denotes None Stationary Series $\quad * *$ Denotes

\section{Stationary Series}

From the KPSS output in Table 1 above, some of the variables were stationary at $I(0)$ while others were stationary at $I(1)$. Running a Johansen and Jasilius co-integration test will yield inconsistent results since all the variables were not stationary at $I(1)$.Thus, the bounds co-integration test by Pesaran (2001) will be conducted and the output of the test is given in Table 2 below.

Table 2. The ARDL Bounds Co-Integration Test

\begin{tabular}{|l|l|l|l|l|}
\multicolumn{4}{|c}{$\mathrm{H}_{0}=\alpha_{1 \mathrm{i}}=\alpha_{2 \mathrm{i}}=\alpha_{3 \mathrm{i}} \ldots \ldots=\alpha_{10 \mathrm{i}}=0$} & $\mathrm{H}_{\mathrm{A}}=\alpha_{1 \mathrm{i}}=\alpha_{2 \mathrm{i}}=\alpha_{3 \mathrm{i}} \ldots \ldots$. \\
\hline Test Statistic & Value & Significance level. & $\mathbf{I}(\mathbf{0})=$ lower bound. & $\mathbf{I}(\mathbf{1})=\alpha_{10 \mathrm{i}} \neq 0$ \\
\hline F-statistic & 12.08179 & $10 \%$ & 1.8 & 2.8 \\
\hline K & 9 & $5 \%$ & 2.04 & 2.08 \\
\hline & & $2.5 \%$ & 2.24 & 3.35 \\
\hline & $1 \%$ & 2.5 & 3.68 \\
\hline
\end{tabular}

Source: Eviews 10Asymptotic: $\mathrm{n}=1000$ 
From the Eviews 10 output in Table 2 above, the calculated F-statistics is 12.08179. Hence, the value of the calculated F-statistics will be compared with the critical values at 5\% level. If the calculated F-statistics lies above the upper level of the bound I(1), the null hypothesis is rejected, and what this means is that there is co-integration among the variables. On the other hand, if the calculated F-statistics falls below the lower level of the bound $\mathrm{I}(0)$, the null hypothesis cannot be rejected, meaning that there is no co-integration among the variables. However, if it falls within the bound, the result is inconclusive. When the computed F-statistic falls inside the upper and lower bounds, a convincing inference cannot be made without knowing the order of integration of the underlying regressors (Narayan, 2004). From Table 2, the lower bound value is 2.04 while the upper bound value is 2.08 . Thus, the Fstatistics of 12.08179 is greater than the upper bound value of 2.08; therefore, the null hypothesis which states that there is no co-integration is rejected in favor of the alternative hypothesis which states that there is co-integration among the variables. Summarily, the variables have long run association and, given this, the long run error correction model can be developed after establishing the error correction term from the residuals of the long run model estimates using ordinary least squares.

Table 3. The Long Run Error Correction Model

\begin{tabular}{|l|l|l|l|l|}
\hline \multicolumn{5}{|l|}{ Dependent Variable: D(NPL) Method: Least Squares Included Observations: 82 after Adjustments } \\
\hline Variable & Coefficient & Std. Error & t-Statistic & Prob. \\
\hline C & 0.004029 & 0.399685 & 0.010081 & 0.9920 \\
\hline D(NPL(-1)) & 0.682905 & 0.471551 & 1.448210 & 0.1520 \\
\hline D(GDP(-1)) & -0.123102 & 0.383589 & -0.320921 & 0.7492 \\
\hline D(INT(-1)) & -0.208224 & 0.169755 & -1.226615 & 0.2241 \\
\hline D(INF(-1)) & 0.194323 & 0.305248 & 0.636607 & 0.5265 \\
\hline D(UNEMP(-1)) & -3.970382 & 5.162780 & -0.769039 & 0.4445 \\
\hline D(EXCH(-1)) & -0.020357 & 0.032954 & -0.617747 & 0.5387 \\
\hline D(LDR(-1)) & 0.140782 & 0.149266 & 0.943164 & 0.3488 \\
\hline D(ROA(-1)) & -0.052443 & 0.547155 & -0.095847 & 0.9239 \\
\hline D(ROE(-1)) & -0.082566 & 0.153983 & -0.536204 & 0.5935 \\
\hline D(BCAR(-1)) & 0.387070 & 0.569392 & 0.679796 & 0.4989 \\
\hline ECT(-1) & -0.120625 & 0.083634 & -1.442291 & 0.1537 \\
\hline Global Statistics. & & \multicolumn{5}{|l|}{ info } & 5.107991 \\
\hline R-squared & 0.320385 & \multicolumn{4}{|l|}{$\begin{array}{l}\text { Akaike } \\
\text { criterion }\end{array}$} \\
\hline Adjusted R-squared & 0.213588 & Schwarz criterion & 5.460194 \\
\hline F-statistic & 2.999955 & $\begin{array}{l}\text { Hannan-Quinn } \\
\text { criter. }\end{array}$ & 5.249395 \\
\hline Prob(F-statistic) & 0.002533 & Durbin-Watson stat & 2.118588 \\
\hline
\end{tabular}

Source: Eviews 10

From Table 3 above, economic growth denoted by GDP growth rate has a negative relationship with NPL. This finding is consistent with economic 
theory. A stable economic growth boosts real income and minimizes the likelihood that a potential borrower will not be able to service his debt, as he will have more disposable income. As such, as the GDP grow, the NPLs in the banking sector reduce (Messai \& Jouini, 2013). However, this relationship is insignificant. More so, there is a negative relationship between interest rate (INT) and NPL which means that higher interest rate reduces NPL. The implication of this result is that as interest rate goes up, borrowers become more averse to loans and existing loan holders reduce their loan portfolio, thus the relationship between interest rate and NPL becomes negative. Furthermore, the relationship between inflation rate (INF) and NPL is positive. By implication, higher inflation rate leads to higher NPL as a result of the variable interest rate structure operational in Nigeria. Due to higher inflation, lenders adjust interest rates to reflect their real values; hence, debt servicing becomes more difficult for inflation- induced -reduced-income -earners who have to pay higher interest rates. High unemployment (UNEMP) rate reduces NPL due to lenders' aversion to extending loans to the unemployed in the first case. The real exchange rate $(\mathrm{EXCH})$ is negatively related to NPL, which implies that exchange rate appreciation in favor of the local currency will reduce NPL if the loans are denominated in foreign currencies. High Loan Deposit Ratio (LDR) increases NPL, while bank profitability indicators (ROA \& ROE) captured in the model have a negative relationship with NPL. By implication, low bank profitability as a result of poor management implies poor skills in credit evaluation and monitoring which translate to more chances of loan default, whereas high bank profitability as a result of sound management implies good skills in credit evaluation and monitoring which reduces the likelihood of loan default. Finally, Bank Capital to Asset Ratio (BCAR) has a positive relationship with future NPL.

The $\mathrm{R}^{2}$ value of $32 \%$, as low as it seems, does not constitute any problem whatsoever since the model is not a predictive model. The model, in compliance with the scope of the study, tries to find the relationship between NPL and some selected macroeconomic and bank specific variables. All the independent variables affect NPL in the long run (as depicted by the significant F-Statistics), but their relationship is insignificant to explain the trend in NPL in the Nigeria banking industry as depicted by their respective insignificant probabilities a 5\% level of significance. Suffice to conclude in this study framework that all the macroeconomic and bank-specific variables captured in this study do no significantly explain credit risk trend (denoted by NPL) in the Nigerian Banking sector. 
Table 4. Breusch-Godfrey Serial Correlation LM Test

\begin{tabular}{|l|l|l|l|}
\hline F-statistic & 0.486754 & Prob. F(2,68) & 0.6167 \\
\hline Obs*R-squared & 1.157367 & Prob. Chi-Square(2) & 0.5606 \\
\hline
\end{tabular}

Source: Eviews 10

From the Table 4 above, the probability of the observed R-squared is 0.5606 , and this is above 5\%. Thus, we accept the null hypothesis which states that the residuals are not serially correlated, and this is desirable.

Table 5. Wald Coefficient Diagnostic Test

\begin{tabular}{|c|c|c|c|}
\hline Test Statistic & Value & Df & Probability \\
\hline F-statistic & 2.999955 & $(11,70)$ & 0.0025 \\
\hline Chi-square & 32.99951 & 11 & 0.0005 \\
\hline
\end{tabular}

Table 5 above shows the result of the Wald coefficient diagnostic test otherwise known as short-run causality test. The goal of this test is to determine the influence of the macroeconomic and bank specific indicators on credit risk. The null hypothesis which states that the macroeconomic and bank specific indicators do not jointly influence credit risk in the Nigeria banking sector in the short run is tested against the alternative hypothesis which states that the macroeconomic and bank specific indicators jointly influence credit risk in the Nigeria banking sector in the short run. Therefore, from the Table 5 above, the chi-square probability value of 0.0005 denotes the rejection of the null hypothesis which states that the macroeconomic and bank specific indicators do not jointly influence credit risk in the Nigeria banking sector in the short run in favor of the alternative hypothesis which states that the macroeconomic and bank specific indicators jointly influence credit risk in the Nigeria banking sector in the short run. 


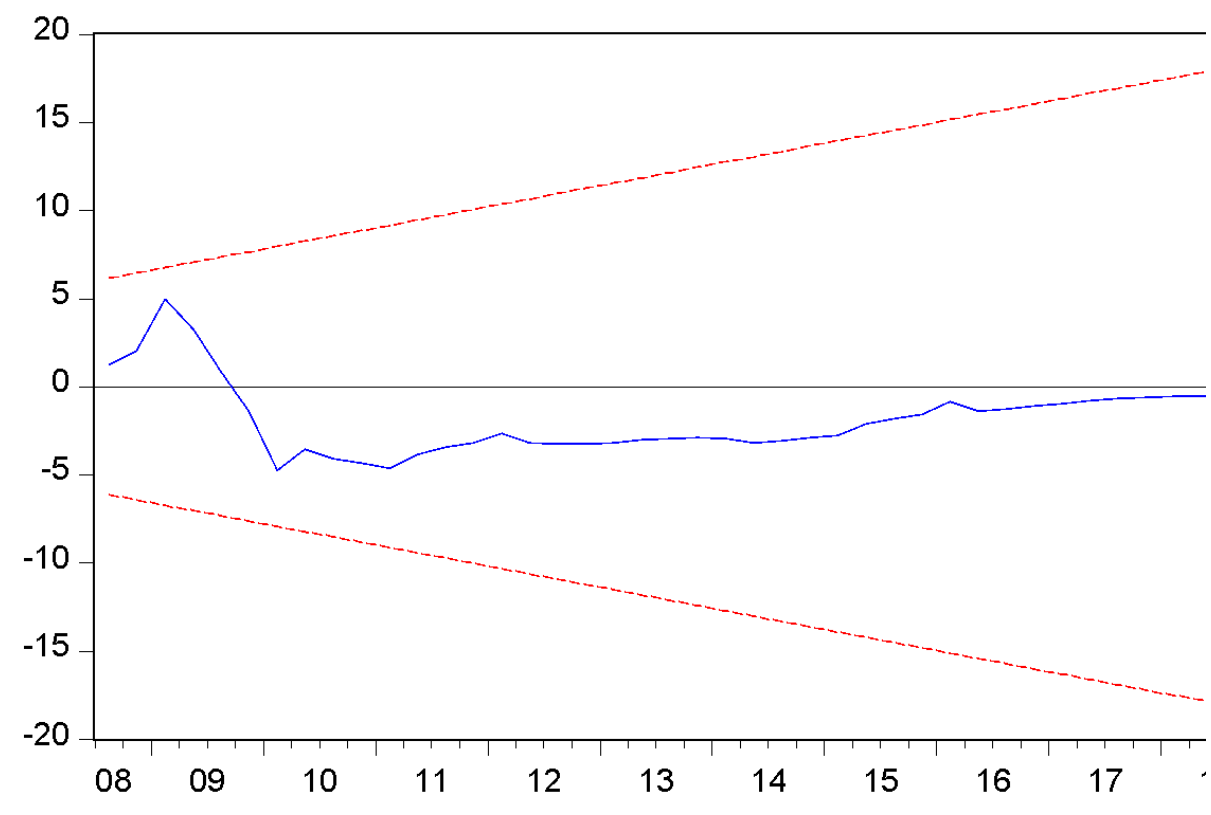

Figure 1. CUSUM Stability Test

From Figure 1 above, the blue line lies between the two red lines indicating that the long run error correction model is stable and devoid of structural changes.

\section{Conclusion and Recommendation}

This study examines the macroeconomic and bank-specific determinants of credit risk in the Nigerian Banking industry. Credit risk, which is often represented by the ratio of non- performing loans to total loan (NPL), is considered as one of the critical factors that causes bank distress in recent times. The inquiries by academics to determine the factors that give rise to credit risk were reinforced by the global financial crises of the last decade. Consequently, a lot of empirical studies (at country level and cross-country level) on the determinants of credit risk have emerged in the literature. There seems to be a consensus of findings in the literature in terms of the negative relationship between credit risks and GDP growth rate. All other macroeconomic and bank-specific factors tend to have an unspecified relationship with credit risk, and their nature of interaction follows a random pattern due to countries' peculiarities.

In this study, GDP growth rate, return on asset (ROA), return on equity (ROE), interest rate (INT), unemployment rate (UNEMP), and real exchange rate $(\mathrm{EXCH})$ were found to have a negative relationship with non-performing 
loans (NPL), while inflation rate (INF), loan deposit ratio (LDR), and ratio of bank capital to asset were found to be positive. Nevertheless, their relationships were found to be insignificant. More so, in as much as these variables jointly influence credit risk as depicted by the F-statistics, this influence is insignificant to explain credit risk trend in the long run. The Wald short-run causality test otherwise known as the Wald coefficient diagnostic test, however, reveals that the macroeconomic and bank specific indicators jointly influence credit risk in the Nigeria banking sector in the short run.

Given the insignificance of the macroeconomic and bank-specific factors that determine credit risk in the Nigerian banking sector, it is imperative to note that some other socioeconomic factors relating to the borrower and the business climate, which were not captured in this study, can also determine credit risk in the Nigerian banking sector. For instance, Nzotta (2018) argues that in certain circumstances, there is a conscious attempt by the borrower to defraud the bank by proposing business activities which are not viable or intended for implementation, thereby diverting the funds. Furthermore, poor project conception, feasibility study, and planning also determine whether the loan will be granted or not.

Nzotta (2018) further pinpointed that the problem of poor infrastructural facilities in Nigeria affects the cost of doing business and the competitiveness of these firms and businesses, while the harsh business environment caused by changes in government policies - especially monetary and fiscal policies measures including regulatory charges- and political instability create challenges for business survival and the ability to honor financial obligations, thus, leading to business failures and non-performing credits. Furthermore, social dislocations and distortions, armed conflicts and insurrection such as the incidence of Boko-haram insurgency culminated in the failure of several businesses in the Northern zone of Nigeria from 2009 till date, thereby creating lost credits or non-performing loans in various banks in the zone.

Based on the foregoing, this study is very careful not to jump to the conclusion that the preponderance of socioeconomic factors determines credit risk in the Nigerian banking sector as this is absolutely an empirical matter. Thus, this study recommends that further empirical research which captures some of these aforementioned socioeconomic factors should be conducted in order to have a holistic view of factors that determine credit risk in the Nigerian banking industry.

\section{References:}

1. Ahmad, N. H. (2003). Credit Risk Determinants: By Institutional Type. Proceedings of Malaysian Finance Association Conference 
2. Ali, A. \& Daly, K. (2010). Macroeconomic determinants of credit risk: Recent evidence from a cross country study. International Review of Financial Analysis, 19(3), pp. 165-171.

3. Angbazo Lazarus, (1997). Commercial banks net interest margins default risk interest rate risks and off balance sheet banking. Journal of Banking and Finance, 2, pp. 55-87.

4. Ari ff, M. \& Marisetty, V. (2001). A New Approach to Modeling Multi- Country Risk Premium Using Panel Data Test Method. Proceedings of MFS conference in Cyprus

5. Behera, S. R. \& Dash, D. P. (2017). The effect of urbanization, energy consumption, and foreign direct investment on the carbon dioxide emission in the SSEA (South and Southeast Asian) region. Renewable and Sustainable Energy Reviews, 70, pp. 96-106.

6. Berger, A. N. \& DeYoung, R. (1997). Problem loans and cost efficiency in commercial banks. Journal of Banking \& Finance, 21(6), pp. 849-870.

7. Bofondi, M. \& Ropele, T. (2011). Macroeconomic determinants of bad loans: evidence from Italian banks. Bank of Italy Working Paper, 89.

8. Castro, V. (2013). Macroeconomic determinants of the credit risk in the banking system: The case of the GIPSI. Economic Modeling, 31, pp. 672-683.

9. Chaibi, H. \& Ftiti, Z. (2015). Credit risk determinants: Evidence from a cross-country study. Research in International Business and Finance, 33(1), pp. 1-16.

10. Cheng, S. (2008). Board Size and the Variability of Corporate Performance, Journal of Financial Economics, 87, pp. 157-176

11. Demirguc-Kunt, A. \& Detragiache, E. (1997). The determinants of banking crises: Evidence from industrial and developing countries. Policy Research Working Paper, No. 1828.

12. Derban, W. K., Binner, J. M. \& Mullineux, A. (2005). Loan repayment performance in community development finance institutions in the UK. Small Business Economics, 25(4), pp. 319-332.

13. Duruibe, S. C. (2018). A Review of the Influence of the Nigerian Banking Sector Evolution on the Nation's Economy- An Autoregressive Distributed Lag Approach to Co-integration. European Journal of Business Research, 17(1), pp. 7-18.

14. Farhani, S. \& Ozturk, I. (2015). Causal relationship between $\mathrm{CO} 2$ emissions , real GDP, energy consumption, financial development , trade ... consumption, financial development, trade openness , Environmental Science and Pollution Research, (October). https://doi.org/10.1007/s11356-015-4767-1 
15. Gavin, M. \& Hausmann, R. (1996). The Roots of Banking Crises: The Macroeconomic Context. IDB Working Paper, 262.

16. Greuning, H. \& Bratanovic, S. B. (2003). Analyzing and Managing Banking Risk: A Framework for Assessing Corporate Governance and Financial Risk, 2nd ed., The World Bank, Washington, DC.

17. Jafari, Y., Othman, J. \& Nor, S. M. (2012). Energy consumption, economic growth and environmental pollutants in Indonesia. Journal of Policy Modeling, 34, pp. 879-889.

18. Katircioglu, S. T., Feridun, M. \& Kilinc, C. (2014). Estimating tourism-induced energy consumption and $\mathrm{CO} 2$ emissions: The case of Cyprus. Renewable and Sustainable Energy Reviews, 29, pp. 634-640.

19. Liang, H. \& Reichert, A. K. (2012). The Impact of Banks and Nonbank Financial Institutions on Economic Growth, The Service Industries Journal, 32(5), 699-717.

20. Louzis, D., Angelos, V. \& Vasilios, L. M. ( 2012). Macroeconomic and bank-specific determinants of non-performing loans in Greece: A comparative study of mortgage, business and consumer loan portfolios. Journal of Banking \& Finance, 36(4), pp. 1012- 1027.

21. Makri, V., Athanasios, T. \& Athanasios, B. ( 2014). Determinants of non-performing loans: The case of Eurozone. Panoeconomicus, 61(2), pp. 193-206.

22. Messai, A. S. \& Jouini, F. (2013). Micro and Macro determinants of non-performing loans. International Journal of Economics and Financial Issues, 3(4), pp. 852-860.

23. Mishkin, F. S. (1996). Understanding financial crises: A developing country perspective. NBER Working Paper, 5600, Cambridge, MA.

24. Nkusu, M. (2011). Non-performing loans and macro- financial vulnerabilities in advanced economies. International Monetary Fund, $11(161), 1$

25. Nzotta, S. M. (2018). Dynamics of bank lending and credit management. Stillmark Media Limited, Owerri.

26. Pesola, J. (2005). Banking fragility and distress: An econometric study of macroeconomic determinants. Bank of Finland Research Discussion Paper, 13.

27. Vogiazas, S. \& Nikolaidou, E. (2011). Credit risk determinants in the Bulgarian banking system and the Greek twin crises. Paper presented in MIBES International conference, 2011, Serres, Greece. 